\title{
Reflections upon practices are important in Social Work
}

Siv Oltedal, Associate Professor, Bodø University College, Norway

E-mail: siv.oltedal@hibo.no 
"I now realise that as a social worker there is need to be creative, for life may throw at you something new that you have never experienced before" writes Zainab Longwe from Malawi in her essay: "Reflections from challenges of working with HIV/Aids affected and infected orphans in Malawi." In spite that the AIDS epidemic is responsible for eight deaths every hour in Malawi, it is still a stigma to disclose such a disease. Zainab worked with orphans and writes about the critical incident she encountered when she met with nine year old Vincent: "The minute that the boy entered the room to greet me, something moved inside me." Death and dying were not talked about to children and this caused more pain and suffering for Vincent. Vincent surprised the social worker Zainab as he asked: "are you ever going to leave me, because everyone I know either leaves or dies like my mother, because I am HIV positive"? This essay deals with the core issue of social work: How to reflect in action as to be able to respond to the problems we as social workers encounter in practice. The role of practice in social work is also important in the article: "A Comparative Analysis of Social Work in Vietnam and Canada: Rebirth and Renewal." Durst, Lanh and Pitzel writes: "Field education is the link from theory to practice and is often where differences between the two countries become evident." The social work profession in Canada is characterized by a strong practice orientation, with for example compulsory field education at the master level. As a new academic field in Vietnam theories more than practices are valued within the universities. There is a challenge for social work in Vietnam to contextualize and adapt social work theories in a way that will help to illuminate reflections upon local practices.

Language training, social studies and work practice can help Non-Western immigrants to access labour marked and neighbourhood arenas, writes Tone Larsen in the article: "Trustdevelopment in Danish and Norwegian integration programmes". By studying similarities and differences between these introduction programmes she analyses how trust can develop within integration practice. Through interviewing people, implementing these programmes, she tries to highlight realities and not only ideologies. To promote social inclusion: "understanding the local language and customs, interpreting the meaning behind actions and knowledge of the receiving society's common logic are necessary conditions for participating in society." Her article shows that it is a challenge for both countries to develop programmes where majority and minority inhabitants mutually interact; which means that both groups can contribute to create more social inclusion in the respective societies.

"Principles of equality and brotherhood used to dominate in the Soviet state. In fact it was only declaration: there still remained inequality between people and society" writes Irina Surkova in the article: "Social Problems in the Russian Army within the Framework of Social Work." This difference between ideology and practice was an issue professional social work was able to explore when they established schools of social work after the end of the Soviet Union. Surkova has studied what kind of social problems social workers within the Russian Army, are working with. Social work within the army is becoming an increasing important field of practice. Surkova writes that unsolved social problems of servicemen may affect these same people who protect the country from danger, and as a result they may become threats themselves.

In this issue of Journal of Social Work we will, for the first time, publish oppositions to a PhD dissertation, namely Ase Vagli's thesis "Behind Closed Doors: Exploring the Institutional Logic of Child Protection Work" which she defended in 2009 at Bergen University, Norway. The first opponent Sue White writes: "I have spent the last fifteen years studying everyday child protection practices in the UK and I recognise many of the issues she raises." Kjersti Ericsson the second opponent, challenges social work to make a comparison to law as another decision-making-system. There is a difference between disciplines that mainly deal with theories for example sociology, anthropology and for those that deal with theory and practice as it is in the field of social work. Studies that illuminate more on theory within the 
social sciences may bring problems as Ericsson underlines in the following quotation: "In her treatment of the topic "inside"/"outside", Vagli, in my opinion, comes dangerously close to reproducing the stereotypes of the emotional, intuitive (female) social worker in contrast to the rational, objective (male) legal expert." Or is it a common challenge for both practical and more theoretical oriented social sciences to deal with and account for complexities?

Reflections upon complexities and practices are important in social work. Being creative is important too, both in research and practice; for life may throw at you something new that you have never experienced before. 